\title{
Cannabinoid Drug Class Measurement
}

National Cancer Institute

\section{Source}

National Cancer Institute. Cannabinoid Drug Class Measurement. NCI Thesaurus. Code C74689.

The determination of the amount of cannabinoid class agents present in a sample. 